\title{
OBSERVATIONS ON ICE-DAMMED SUMMIT LAKE, BRITISH COLUMBIA, CANADA
}

\author{
By R. Gilbert \\ (Department of Geography, University of British Columbia, Vancouver 8, Canada)
}

\begin{abstract}
Testing of a water-balance equation for the Summit Lake basin in July and August I 968 indicated that, $2 \frac{1}{2}$ months before its fourth known draining, there existed a leak through or under the damming glacier that may have been as large as $3-5 \mathrm{~m}^{3} / \mathrm{s}$. Lake temperatures recorded during the same period indicate water at $0.5^{-0}-8^{\circ} \mathrm{C}$ near the ice dam and up to $2.6^{\circ} \mathrm{C} 4^{-5} \mathrm{~km}$ from the dam. These observations support the proposal of Liestøl (1956) and Mathews (in press) of tunnel enlargement by melting. It is calculated that lake water temperatures of $0.25,0.9$ and $0.15^{\circ} \mathrm{C}$ are required to account for the November
\end{abstract} 1965 , September 1967 and November 1968 drainings, respectively.

RÉsumé. Observations sur le Summit Lake fermé par un barrage de glace, Colombie Britannique, Canada. L'établissement d'une équation de bilan hydrologique pour le bassin du Summit Lake en juillet et août 1968 montre que, 2 mois $1 / 2$ avant son quatrième épisode connu d'assèchement, il existait, à travers ou en dessous du glacier formant barrage, une fuite qui peut avoir été de l'ordre de 3 à $5 \mathrm{~m}^{3} / \mathrm{s}$. La température du lac enregistrée durant la même période montre que l'eau était à $0,5-0,8^{\circ} \mathrm{C}$ prés du barrage de glace et montait à $2,6^{\circ} \mathrm{C}$ à 4 ou $5 \mathrm{~km}$ du barrage. Ces observations sont en harmonie avec l'hypothèse de Liestøl (1956) et de Mathews (in press) d'un élargissement du tunnel par fusion. On a calculé que des températures de l'eau du lac de $0,25,0,9$ et $0,15^{\circ} \mathrm{C}$ sont nécessaires pour rendre compte des assèchements respectifs de novembre 1965 , septembre 1967 et novembre 1968 .

Zusammenfassung. Beobachtungen am Eisstausee Summit Lake, British Columbia, Kanada. Die Prüfung einer Wasserhaushaltsgleichung für das Einzugsgebiet des Summit Lake im Juli und August r968 wies darauf hin, dass $2 \frac{1}{2}$ Monate vor dem vierten bekannten Ausfluss ein Ablauf mit einer Kapazität von etwa $3^{-5} \mathrm{~m}^{3} / \mathrm{s}$ durch den oder unter dem abdämmenden Gletscher bestand. Die während die selbe Periode gemessenen Wassertemperaturen im See ergeben $0,5^{-0}, 8^{\circ} \mathrm{C}$ nahe dem Eisdamm und bis zu $2,6^{\circ} \mathrm{C}$ in $4^{-5} \mathrm{~km}$ Entfernung vom Damm. Diese Beobachtungen stützen die Annahme von einer Tunnelvergrösserung durch Schmelzen von Liestøl (1956) und Mathews (in press). Es wurde berechnet, dass Seewassertemperaturen von o,25, o,9 und $0,15{ }^{\circ} \mathrm{C}$ notwendig sind, um die jeweils entsprechenden Ausflüsse im November 1965 , im September I 967 und im November 1968 zu erklären.

\section{INTRODUCTION}

Drainings of Summit Lake, British Columbia, have been observed in December I96is November 1965, September 1967 and December 1968 (Mathews, 1965; in press). Draining, were not reported from the beginning of human occupance of the area about rgoo until ig6r. The investigation reported here was designed to test the hypothesis that an appreciable leak in the ice dam occurred some months before the lake began to drain, and to study the role of the heat content of the lake water in enlarging the passage or passages through which the draining occurred.

\section{The WATER-BALANGe MOdel}

Preliminary observations of the rate of filling of Summit Lake after the ${ }_{1} 6_{5}$ draining indicate that a leak of appreciable size through or under the damming Salmon Glacier may have existed at least a month before the next draining was first noticed on 12 September I967. The proposed leak may be expressed in terms of a simple water-balance equation:

$$
Q_{\mathrm{ol}}=Q_{\mathrm{i}}+P-\Delta V-Q_{\mathrm{on}}-E
$$

where $Q_{\mathrm{ol}}$ is the flow through the proposed leak; $Q_{\mathrm{i}}$ is the inflow to the lake; $P$ is the precipitation on the lake surface; $\Delta V$ is the volume change of the lake water; $Q_{o n}$ is the overflow to the north from the lake; $E$ is the evaporation from the lake surface.

This model was tested in 1968 in an attempt to establish the existence of a leak. Inflow was measured through most of July, August and September on four streams draining the east side of the Summit Lake basin and for shorter periods on two streams on the west side (Fig. I). 
The flow from several of these streams was used to estimate the inflow from the rest of the basin except for Salmon Glacier. These estimates were based on the similarity of landscape and on the non-significance of Student's " $t$ " tests on paired variables of daily run-off of streams in adjacent areas. Whenever doubt existed, an effort was made to underestimate inflow in order to be more certain that if a leak were detected this conclusion would be valid. Inflow from that area of Salmon Glacier, which, on the basis of ice-surface topography, is tributary to Summit Lake, was estimated from spot readings of ablation and from the ablation and run-off data for the adjacent Berendon Glacier, which is of similar size, aspect and elevation. Because of the uncertainty of the area of Salmon Glacier actually contributing inflow, a further underestimate was provided by considering all, three-quarters, two-thirds, one-half and one-third of this area in the calculation of inflow.

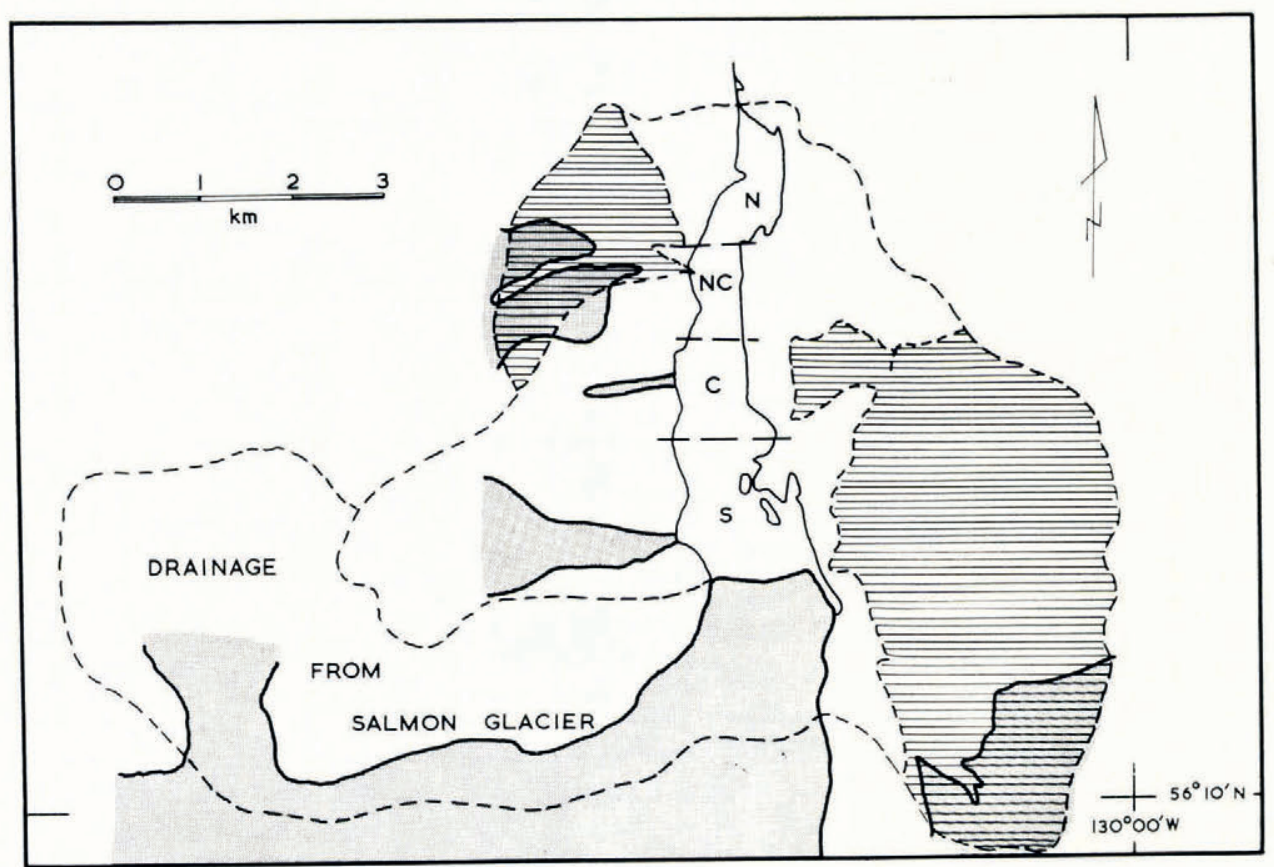

Fig. I. Drainage basin of Summit Lake. Stipple indicates present glaciers; horizontal shading represents areas on which discharge measurements were made in 1968 . For presentation of water-temperature results, the lake is divided into four parts: north $(\mathcal{N})$, north central $(\mathcal{N} C)$, central $(C)$ and south $(S)$.

The other terms of the water balance were measured or estimated through the same period. From air photographs taken on 4 August I968, when the lake was about $33 \mathrm{~m}$ below the level when full, a large-scale contour map of the exposed lake bed was compiled by the Topographic Survey of the Department of Energy, Mines and Resources. From this map, a linear hypsographic relation was established. This with twice-daily water-surface elevation readings provided a measure of the daily water-volume change $(\Delta V)$. Of the remaining terms of the water balance, precipitation on the lake was estimated from rain gauges at each end of the lake, overflow to the north in 1968 was zero, and evaporation from the lake was considered small enough to ignore since much of the lake surface was covered with floating ice, the water temperature was close to $0^{\circ} \mathrm{C}$, and cool damp air was noted pooled over the lake surface much of the time. 
A Student's " $t$ " test on the difference between the paired daily values of total input to the lake $\left(Q_{\mathrm{i}}+P\right)$ and the volume change in the lake $(\Delta V)$ was performed for the periods I $^{-}{ }^{-}{ }^{1}$ July and I-3 I August I 968 with the result that for the first period a leak significant at $95 \%$ confidence was detected only when all of the area of the Salmon Glacier tributary to Summit Lake was considered. For the second period a significant leak could be detected when less than one-half of this area was considered, and with all the area the average leak was calculated as $3 \mathrm{~m}^{3} / \mathrm{s}$. Were less conservative estimates of total input taken into consideration, the leak may have been as large as $5 \mathrm{~m}^{3} / \mathrm{s}$.

The fourth recorded draining of Summit Lake occurred in mid-November 1968.
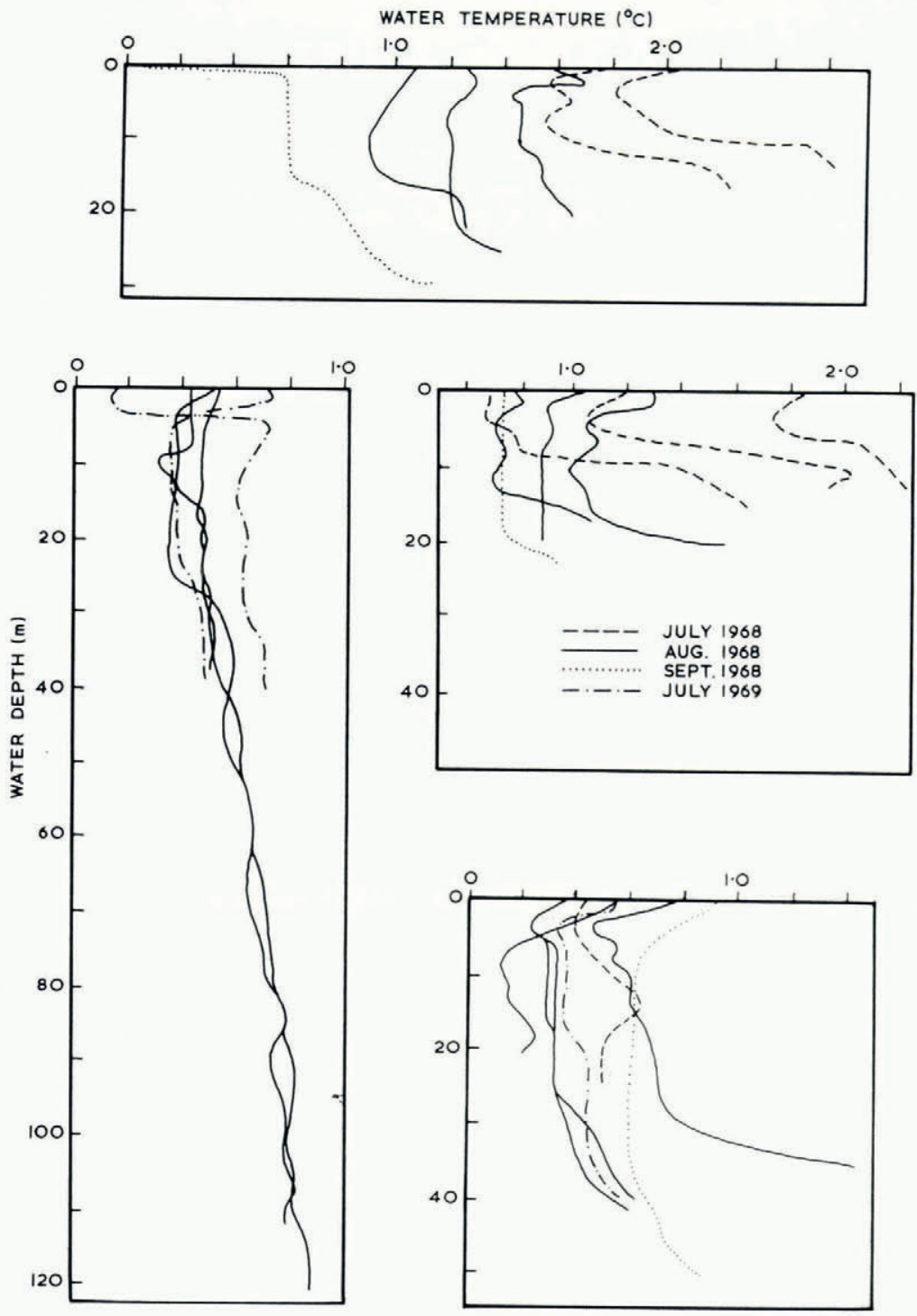

Fig. 2. Temperature profiles in Summit Lake, 1968 and 1969. 


\section{LAKE WATER TEMPERATURES}

A thermistor on a $124 \mathrm{~m}$ cable was used to record lake temperatures from surface to bottom at $1.5 \mathrm{~m}$ intervals through the summer of 1968 and in July I969 (Fig. 2). Because of the paucity of data, it is impossible to calculate the mean water temperature for the whole lake, but it appears that the mean in July may have been approximately $0.8^{\circ} \mathrm{C}$, about $0.6^{\circ} \mathrm{C}$ in September and perhaps as low as $0.3^{\circ} \mathrm{C}$ in November when the draining occurred. The July 1969 temperatures agree reasonably well with the 1968 results.

\section{Significance FOR THE DRAINING EVENT}

Liestøl (1956, p. 123) stated that if "the water from the lake has in some way forced a small passage beneath the ice it will, by melting, be able to extend and keep open a tunnel". That is, the volume of ice melted from the tunnel to a given instant is a function of the total amount of water that has passed through the tunnel. For Summit Lake, the obvious draining mechanisms of overtopping or floating of the ice dam by the lake water are not feasible. The mechanism of Liestøl provides a plausible explanation of the draining events if the existence of a tunnel some time prior to draining can be established and if it can be shown that the heat energy available or generated is sufficient to enlarge the tunnel at the rate required.

Mathews (in press) calculated the heat available from the potential energy loss for lake water temperatures of $0^{\circ} \mathrm{C}$. If temperatures above $0^{\circ} \mathrm{C}$ are considered, the equation for tunnel-exit temperature becomes:

$$
\theta=\frac{Q \rho_{\mathrm{w}} g H}{h \pi D L}\left[\mathrm{I}-\exp \left(-\frac{h \pi D l}{Q \rho_{\mathrm{w}} c}\right)\right]+\theta_{1} \exp \left(-\frac{h \pi D l}{Q \rho_{\mathrm{w}} c}\right)
$$

where $D$ is the tunnel diameter in meters;

$\theta$ is the tunnel water temperature in deg;

$Q$ is the discharge in the tunnel in $\mathrm{m}^{3} \mathrm{~s}^{-1}$;

$\rho_{\mathrm{w}}$ is the density of water in $\mathrm{kg} \mathrm{m}^{-3}$;

$H$ is the head in meters;

$h$ is the coefficient of heat transfer in $\mathrm{W} \mathrm{m}^{-2} \mathrm{deg}^{-1}$;

$L$ is the horizontal tunnel length in meters;

$l$ is the horizontal distance down the tunnel in meters at which the temperature is taken;

$c$ is the specific heat of water in $\mathrm{J} \mathrm{kg}^{-1} \mathrm{deg}^{-1}$;

$\theta_{1}$ is the lake water temperature in deg.

Tunnel exit temperatures $(l=L)$ are evaluated in Table I, assuming lake water temperatures from $0^{\circ}$ to $1.4^{\circ} \mathrm{C}$ for the 1965,1967 and 1968 drainings.

It can be seen that in the early stages of the flood nearly all the heat content of the lake is advected to the ice. In the terminal stages the amount drops to $35 \%$.

As a check on the feasibility of tunnel enlargement by melting, the ice melt at each time during the drainings given by Mathews (in press) and for the 1968 draining may be calculated as:

$$
M=\frac{\rho_{\mathrm{w}} Q_{\mathrm{ol}}}{\rho_{\mathrm{i}} F}\left[g H+c\left(\theta_{\mathrm{l}}-\theta\right)\right]
$$

where $M$ is the ice melted in $\mathrm{m}^{3} \mathrm{~s}^{-1}$;

$\rho$ is the density of water $(w)$ and ice $(i)$ in $\mathrm{kg} \mathrm{m}^{-3}$;

$Q_{\mathrm{ol}}$ is the tunnel discharge in $\mathrm{m}^{3} \mathrm{~s}^{-1}$;

$F$ is the heat of fusion of ice in $\mathrm{J} \mathrm{kg}^{-1}$; 
$g$ is the acceleration due to gravity in $\mathrm{m} \mathrm{s}^{-2}$;

$H$ is the vertical drop in $\mathrm{m}$;

$\theta$ and $\theta_{1}$ are the outlet and lake temperatures respectively in ${ }^{\circ} \mathrm{C}$.

The kinetic energy of the water leaving the tunnel is not considered, since it is in the order of $0.5^{-1} \%$ of the loss in potential energy (Mathews, in press). As an approximation to the ice melt in each period, the average of the instantaneous rates of ice melt at the beginning and end of the period was multiplied by the duration of the interval. In the terminal stages of the November 1965, September 1967 and November 1968 drainings, lake water temperatures of $0.25,0.9$ and $0.15{ }^{\circ} \mathrm{C}$, respectively, are required to completely explain the enlarging of the tunnel by this mechanism. The September 1967 temperature is in accord with the water-temperature observations in September 1969, and the two November temperatures seem reasonable for a period when the lake surface is snow- and ice-covered, and inflow of warm stream water is very low.

If the pressure of the overburden of ice tends to close the tunnel at the same time as it is melting, somewhat higher water temperatures would be required to explain enlarging. Also, it is noted that only in the terminal stages of the draining are positive lake temperatures required. This agrees with the observation that the coldest water in the lake is found near the dam, thus being the first to pass through. The warmer water at the north end of the lake would pass through near the end of the flood.

TABle I. Summit LAKe tUNnel exit temperatures for initial Water temperatures from $0^{\circ}$ To $\mathrm{I} .4^{\circ} \mathrm{C}$

\begin{tabular}{|c|c|c|c|c|c|c|c|c|c|}
\hline \multicolumn{2}{|c|}{ Date and time } & \multicolumn{8}{|c|}{ Initial water temperature $\left(\theta_{1}\right){ }^{\circ} \mathrm{C}$} \\
\hline 1965 & & 0.0 & 0.2 & 0.4 & 0.6 & 0.8 & 1.o & 1.2 & I. 4 \\
\hline 1 I November & & 0.08 & 0.08 & 0.08 & 0.08 & 0.08 & 0.08 & 0.08 & 0.08 \\
\hline 18 November & & 0.14 & 0.14 & 0.14 & 0.14 & 0.14 & 0.14 & 0.14 & 0.14 \\
\hline 25 November & & 0.36 & 0.36 & 0.37 & 0.37 & 0.37 & $0.3^{8}$ & $0.3^{8}$ & 0.39 \\
\hline 26 November & & 0.44 & 0.45 & $0.4^{6}$ & $0.4^{6}$ & 0.47 & $0.4^{8}$ & 0.49 & $0.5^{\circ}$ \\
\hline 27 November & ${ }^{1} 5 \cdot 30$ & 0.56 & $0.5^{8}$ & 0.60 & $0.6_{2}$ & 0.64 & o.66 & 0.68 & 0.70 \\
\hline 28 November & 10.00 & 0.66 & 0.69 & 0.72 & 0.76 & 0.79 & $0.8_{3}$ & 0.86 & 0.89 \\
\hline 29 November & 12.00 & 0.84 & 0.90 & 0.97 & 1.03 & 1.09 & 1. 16 & 1.22 & 1.29 \\
\hline 30 November & 10.30 & 0.95 & I.05 & 1.15 & 1.24 & 1.34 & 1.44 & 1. 54 & I. 64 \\
\hline I December & 06.00 & 0.80 & 0.93 & 1.07 & I. 20 & I. 33 & $1.4^{6}$ & I. 60 & 1.73 \\
\hline \multicolumn{10}{|l|}{ I967 } \\
\hline 10 September & 12.00 & 0.22 & 0.22 & 0.22 & 0.22 & 0.22 & 0.22 & 0.22 & 0.22 \\
\hline I I September & 12.00 & 0.28 & 0.28 & 0.28 & 0.28 & 0.29 & 0.29 & 0.29 & 0.29 \\
\hline 12 September & 12.00 & 0.37 & 0.37 & $0.3^{8}$ & $0.3^{8}$ & 0.39 & 0.39 & 0.40 & 0.40 \\
\hline I3 September & 12.00 & 0.47 & $0.4^{8}$ & 0.49 & 0.50 & $0.5^{\mathrm{I}}$ & 0.53 & 0.54 & 0.55 \\
\hline 14 September & 12.00 & 0.57 & 0.59 & $0.6 \mathrm{I}$ & 0.64 & 0.66 & 0.68 & 0.70 & 0.73 \\
\hline I5 September & 12.00 & 0.73 & 0.77 & 0.82 & 0.86 & $0.9^{1}$ & 0.95 & 1.00 & I.04 \\
\hline I6 September & 12.00 & $0.9^{2}$ & 1.00 & 1.08 & 1.17 & 1.25 & 1.33 & I. $4^{\mathrm{I}}$ & I. 49 \\
\hline 17 September & 12.00 & I.04 & 1.16 & 1.26 & 1.39 & $1.5^{1}$ & 1. 63 & I. 75 & 1. .86 \\
\hline 17 September & 18.20 & 1.05 & 1.18 & $\mathrm{I} \cdot 3 \mathrm{I}$ & I. 44 & I. 57 & 1.70 & I. 83 & I. 96 \\
\hline \multicolumn{10}{|l|}{ I968 } \\
\hline I4 November & 12.00 & 0.55 & 0.56 & $0.5^{8}$ & 0.60 & $0.6 \mathrm{I}$ & o.63 & 0.65 & o. 66 \\
\hline I5 November & 12.00 & 0.60 & 0.62 & 0.65 & 0.67 & o.69 & $0.7 \mathrm{I}$ & 0.74 & 0.75 \\
\hline I6 November & 12.00 & 0.70 & 0.74 & 0.77 & $0.8 \mathrm{I}$ & 0.85 & 0.88 & 0.92 & 0.95 \\
\hline I 7 November & 00.00 & 0.75 & 0.79 & 0.83 & 0.88 & $0.9^{2}$ & 0.96 & 1.01 & I.05 \\
\hline 17 November & 12.00 & 0.78 & 0.83 & 0.88 & 0.93 & 0.97 & 1.02 & 1.07 & I. I 2 \\
\hline I 8 November & 00.00 & 0.80 & 0.85 & 0.90 & 0.96 & I.OI & 1.06 & 1.12 & I. 17 \\
\hline 18 November & I 2.00 & 0.84 & 0.91 & 0.97 & 1.04 & 1.10 & 1.17 & 1.24 & I. 30 \\
\hline I9 November & 00.00 & $0.9^{2}$ & I.OI & 1.10 & 1.19 & 1.28 & 1. 37 & 1. 46 & 1.55 \\
\hline I9 November & 06.00 & 0.93 & 1.03 & I. 12 & 1.22 & 1.32 & I. $4^{\mathrm{I}}$ & $1.5^{1}$ & I. $6 \mathrm{I}$ \\
\hline I9 November & 12.00 & 0.93 & 1.03 & I. 14 & 1.24 & 1. 34 & 1.45 & I. 55 & г. 66 \\
\hline I9 November & 18.00 & $0.9 \mathrm{I}$ & 1.02 & I. 13 & 1.24 & I. 34 & I. 45 & 1. 56 & 1. 67 \\
\hline 19 November & 23.00 & 0.86 & 0.97 & 1.09 & 1.20 & 1.31 & 1. 43 & 1.54 & I. 65 \\
\hline
\end{tabular}


The availability of lake water with temperature above $0^{\circ} \mathrm{C}$ provides one answer to the problem raised by Mathews (in press) of no heat available at the upper end of the tunnel and thus no enlargement until some distance down-stream.

\section{Conclusions}

The mechanism of draining by tunnel enlargement proposed by Liestøl (1956) is reasonable for Summit Lake since

i. It is shown in this work and in the work of Fisher (in press) that Summit Lake was leaking through or under Salmon Glacier at least 3 months before the draining occurred.

ii. The calculations leading to the conclusion that lake water temperatures reasonably close to those observed for September and inferred for early winter are sufficient to account for the enlarging of the tunnel at the rate calculated by Mathews (in press).

Clearly, the question of whether the tunnel closes completely after draining cannot be answered, although the results of this study hint that the leak was smaller in July I968 than in August. The evidence is not strong enough to conclude that the leak started at zero sometime after the lake began to refill and that it continued to enlarge until the lake emptied; nor can the questions be tackled of why draining did not occur before ig6r and whether a leak existed some time before that draining except to note that rapid wasting of Salmon Glacier has been observed (Haumann, r96o; Gilbert, unpublished) since the first records early in the century. This wasting may represent the tipping of a balance which may have existed prior to $196 \mathrm{r}$ between the enlarging of a small tunnel by the mechanism described and the rate of closure due to the overburden of ice.

\section{ACKNOWLEDGEMENTS}

This paper represents a summary of an M.A. study carried out at the University of British Columbia with the field assistance of the Cordillera Section, Glaciology Subdivision of the Government of Canada, under Dr A. D. Stanley. The advice and criticism of Professors W. H. Mathews and J. R. Mackay are appreciated by their adoption.

MS. received 9 June 1970

\section{REFERENCES}

Fisher, D. In press. Subglacial leakage of Summit Lake, British Columbia, by dye determinations. Union Géodésique et Géophysique Internationale. Association Internationale d'Hydrologie Scientifique. Commission de Neiges et Glaces. Symposium on the hydrology of glaciers, Cambridge, 7-13 September 1969, organized by the Glaciological Society.

Gilbert, R. Unpublished. Some aspects of the hydrology of ice-dammed lakes: observations on Summit Lake, British Columbia. [M.A. thesis, Dept. of Geology, University of British Columbia, 1969.]

Haumann, D. 1960. Photogrammetric and glaciological studies of Salmon Glacier. Arctic, Vol. 13, No. 2, p. $74^{-1} 10$.

Liestøl, O. 1956. Glacier-dammed lakes in Norway. Norsk Geografisk Tidsskrift, Bd. 15, Ht. 3-4, 1955-56, p. 122-49.

Mathews, W. H. I965. Two self-dumping ice-dammed lakes in British Columbia. Geographical Review, Vol. 55, No. I, p. $46-52$.

Mathews, W. H. In press. Record of two jökullhlaups. Union Géodésique et Géophysique Internationale. Association Internationale d'Hydrologie Scientifique. Commission de Neiges et Glaces. Symposium on the hydrology of glaciers, Cambridge, 7-13 September 1969 , organized by the Glaciological Society. 